\title{
COLLABORATION PERSPECTIVES DEVELOPING SUSTAINABLE AGRICULTURE: THE CASE OF LITHUANIAN FARMERS
}

\author{
Julius Ramanauskas ${ }^{1}$, Milita Vienažindiené2, \\ Jolanta Rauluškevičiené ${ }^{3}$, Jan Žukovskis ${ }^{4}$
}

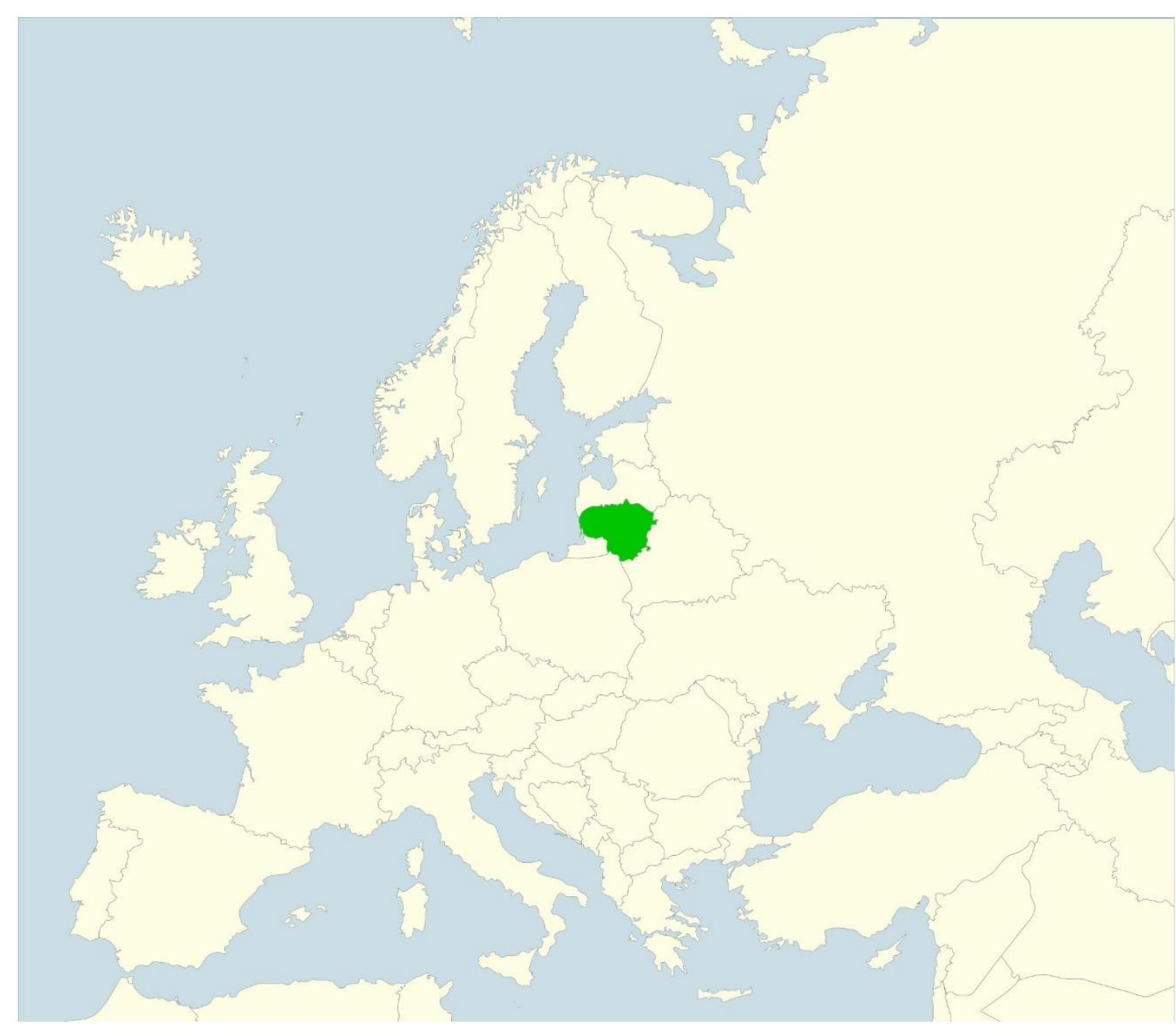

\footnotetext{
1 Prof. habil. Dr. Julius Ramanauskas, Klaipėda University, Lithuania; ORCID: 0000-0001-6250-3103, e-mail: juliuss.ramanauskas@gmail.com;

${ }^{2}$ Assoc. Prof. Milita Vienažindienè, Vytautas Magnus University, Kaunas, Lithuania; ORCID: 0000-0001-9894-6811, e-mail: milita.vienazindiene@vdu.It;

3 Jolanta Rauluškevičienè, Vytautas Magnus University, Kaunas, Lithuania; ORCID: 0000-0002-2578-8338, e-mail: erjolanta@yahoo.com;

${ }^{4}$ Prof. dr. Jan Žukovskis, Vytautas Magnus University Kaunas, Lithuania; ORCID: 0000-0002-8124-9195, e-mail: jan.zukovskis@vdu.It.
} 
Abstract: Sustainable agriculture and active collaboration between farmers are important concepts that have a significant impact on the development of sustainable agriculture, in striving for social and economic development, as well as supporting the reduction of impact to environment. Based on a systematic and comparative analysis, this study highlights the role of collaboration towards developing sustainable agriculture. The overall results imply that more active farmers collaboration requires more active sharing of experience, knowledge and information through meetings or seminars by creating an information portal or platform. These measures could lead to more qualitative communication, more open information sharing, mutual trust and risk reduction, which would ensure the development of sustainable agriculture.

Key words: collaboration, sustainable agriculture, sustainable agriculture development, factors for collaboration.

Santrauka: Darni žemdirbystė ir ūkininkų aktyvus bendradarbiavimas yra svarbios koncepcijos, darančios didelę jtaką vystant darnią žemdirbystę, siekdamos socialinès ir ekonominès plètros, taip pat remdamos poveikio aplinkai mažinimą. Remiantis sistemine analize straipsnyje išryškinama bendradarbiavimo svarba, siekiant darnaus žemès ūkio vystymo. Tyrimo rezultatai atskleidžia, kad siekiant aktyvesnio ūkininkų bendradarbiavimo, reikia aktyviau dalintis patirtimi, žiniomis ir informacija, organizuojant susitikimus ar seminarus, sukuriant informacijos portalą ar platformą. Šiomis priemonėmis galima būtų pasiekti kokybiškesnio bendravimo, atviresnio dalijimosi informacija, tarpusavio pasitikèjimo, sumažinti riziką ir tai užtikrintų darnaus žemès ūkio vystymąsi.

Raktiniai žodžiai: bendradarbiavimas, darnus žemès ūkis, darnaus žemès ūkio vystymas, bendradarbiavimo veiksniai.

\section{Highlights:}

- Collaboration is the key for sustainable agricultural development.

- Through collaboration, agricultural operators have the opportunity to share their assets and opportunities.

- The practice of collaboration between Lithuanian farmers is insufficiently developed.

- Lack of information, distrust in the quality of work, the desire to be independent, the fear of risk-sharing techniques are the main obstacles to non-collaboration.

- Active sharing of experience, knowledge and information through meetings and an information portal would ensure more active collaboration between farmers.

\section{Introduction}

In recent years, due to the loss of natural capital, there has been an increasing talk about the importance of development of sustainable development. It is observed that the potential of nature's productivity is decreasing rapidly, the nature is constantly polluted and otherwise exhausted, and renewable resources are being used at high rates to meet increasing needs, therefore the nature has no time to restore them. Therefore, it is particularly important to pay attention to agriculture as the most closely connected human activity with nature, where the negative consequences of human activity come to the fore here. Kata and Kusz (2015) studies show that agricultural producers are key players in a sustainable agriculture because they are directly involved in the processes that determine development and efficiency of sustainability concept. This presupposes the idea that achieving sustainable agriculture is one of the greatest challenges of the XXI century, requiring major change. Part of the sustainability-oriented change 
is due to scientific and technological innovation, but the most important part of the change is due to changes in people's thinking towards sustainability and desire to increase collaboration for sustainability.

In recent decades, world's scientists, politicians and society as a whole have developed a universal concept that helps to achieve environmental goals without negating the economic and social interests of society and that is a sustainable development, which has become a vision for the development of developed states. Over recent decades, many countries have integrated a striving for sustainable development into many policy areas, including the common agricultural policy, which aims to promote sustainable farming from economic, social and environmental point of view (Vitunskienè, Vinciūnienè, 2014). Analysis of the studies carried out by scientists noted that sustainable development is understood and defined very differently in scientific works, so the abundance of aspects included in this concept makes it a subject of debate. According to Earles (2005), sustainable agriculture is one that: produces abundant food without depleting land resources or polluting the environment; is based on natural principles, giving priority to ecology both in the development of crop and livestock production and in any other activity. Another important feature, in order the emissions of harmful substances in nature are no higher than nature itself can absorb, is agriculture of social values, the success of which is inseparable from viable rural communities, rich farming families and healthy food for everyone. Vitunskienè et al., (2014) particularizes that sustainable agriculture is one that is economically profitable for farmers, preserves and improves the environment, contributes to the welfare of farmers and fosters the local community. However, the development of sustainable agriculture requires collaboration from participants all around the world to cope with the challenges of consumer expectations, limited resources, international policy and regulation.

Most scientists agree with the statement that collaboration between farmers is recognised as a way of implementing the principles of sustainable agriculture expression and is particularly important in its potential to address the issues related to agricultural products' competitiveness, risk, costs, incomes and other relevant issues. According to Dania et al. (2018), farmers can collaborate during harvesting to reduce resources and handling costs. This will help farmers or agricultural businesses that have limited access to resources, technology, information and skills, to maintain their operations and improve quality and availability of their food by placing them on the market. In addition, information sharing can reduce uncertainty. Collaboration between farmers is increasingly recognised as useful for the successful management and development of sustainable agriculture (Prager, 2015). Most scientists emphasize that the development of sustainable agriculture can be ensured only through active collaboration between farmers, agricultural suppliers, food processors, consumers, scientific circles and policy makers. Jarrett et al. (2015) state, „coordinated and collaborative initiatives have the ability to improve ecological conditions; increase the cost-effectiveness of individual actions; improve productivity (in some cases); bolster social cohesion and knowledge exchange within the farming community; help tackle local land management issues; and positively engage the wider community in landscape scale conservation“ (p. 64). According to Sutherland et al. (2015), „collaboration has also been identified as important in relation to ensuring social and economic sustainability of farming" (p. 83). Sulewski et al. (2018) note that „family farms are the best hope for a sustainable future for farming and for humanity; however, this requires reaching a harmony between environmental, social and economic perspectives of sustainability" (p. 2).

Sustainable agriculture and active collaboration between farmers are important concepts that have a significant impact on the development of sustainable agriculture, in striving for social and economic development, as well as supporting the reduction of impact to environment. The aim of this article is to determine the perspectives of farmers' collaboration developing sustainable agriculture. The paper is organised as follows. The next two sections provide an analysis of the scientific literature on the concept and dimensions of sustainable agriculture, importance of collaboration for sustainable agriculture development, and factors affecting the collaboration of farmers. Section 3 presents research methods, and Section 4 examines practice of Lithuanian farmers' collaboration in striving for sustainable farming. The final stage of this paper consists of general conclusions based on the analysis. 


\section{Theoretical background}

\subsection{The Concept of Sustainable Agriculture Development}

The agricultural sector is one of the areas where sustainability needs to be addressed due to the large use and diversity of natural resources, the satisfaction of human nutritional needs and the survival of food-dependent communities, since many of the current production methods are harmful to the environment and are a major source of greenhouse gas emissions (Rodríguez, 2019; Gołębiewska et al., 2020).

Analysis of scientific literature on the characteristics of sustainable agriculture and its development, showed plenty of interpretations, indicating that the concept of sustainable agricultural development is still being actively debated. According to Vitunskienè et al. (2014), sustainability should be understood as a certain state, whereas sustainable development would mean a way of achieving this state. Publication of G. H. Brundtland's report in 1987 is seen as a starting point that stimulated international understanding and discourse on the global importance of sustainable development. The report notes that "sustainable development is a development that meets current needs of society without reducing the ability of future generations to meet their own needs" (World Commission..., 1987). When thinking about the sustainable agriculture, some authors emphasize the agriculture's ability to maintain system's productivity for as long as possible. Others define sustainable agriculture as a management strategy intended to tackle the main problems of food quality and environmental protection. The third authors focus on flexibility as the agriculture's ability to adapt to future changes. Sustainable agriculture is often treated through individual elements such as organic farming, food quality and safety, rational use of natural resources. Common agricultural policy of the EU is increasingly focused on organic farming, which brings both environmental and economic and social benefits, and is consistent with the components of the sustainable development concept (Čiegis, 2009). The most common and recognised as a comprehensive sustainable agriculture definition, is assigned to the USDA (1990), in which sustainable agriculture is interpreted as a particular territory characterised by a system of integrated plant and animal production activities, which in the long term satisfies basic human food and fibre needs, improves quality of natural environment and potential of natural resources, endeavours to more efficient use of non renewable resources and, where appropriate, integrates natural biological cycles and controls, supports economic viability of agricultural activity, improves life quality of farmers and entire society. According to Lubell et al., the main objective of sustainable agriculture programmes is to encourage farmers to adopt practices that together bring economic, ecological and social benefits (Lubell et al., 2011). Sustainable agriculture stands on four pillars: land management, resource management, human interface, and the ecosystem interface (Shelef et al., 2018).

It is worth noting that existence of different concepts of sustainable agriculture does not necessarily lead to conflicts. On the contrary, diversity and interpretation of sustainable agricultural approaches are more complementary and are necessary for the development of sustainable agriculture.

Despite the active debate, in the scientific literature the authors agree (Dania et al., 2018; Azevedo et al., 2018; Ding et al., 2018; Jarrett et al., 2015; Thomson et al., 2017; Vilkè et al., 2020; Sulewski et al., 2018; Wilson, 2017; Velten et al., 2015; Čiegis, 2009, etc.) that the concept of sustainable agriculture combines three main aspects: economic, environmental and social.

Economic aspect of sustainability includes sustainable creation of financial well-being and economic activity through efficient use of financial resources, reducing waste and saving costs, while ensuring high productivity, consumer satisfaction and service levels. According to the authors (Golebiewska et al., 2020; Wilson, 2017; Thomson et al., 2017; Sulewski et al., 2018, etc.) the prerequisites for the sustainable development of agriculture in economic terms are created when farms are able to generate income that not only creates a satisfactory life quality for farmers, but also restores the capital used during production and preserves business in the long term prospect.

Environmental aspect means conservation and improvement of natural resources by reducing the use of non-renewable resources and greenhouse gas emissions, control of water and soil 
pollution, control of fertiliser and pesticide use, smart waste management and environmental legislation. In other words, avoiding activities that harm the environment, food quality or health of farmers and consumers. In addition, the authors (Bélanger et al., 2012; Dania et al., 2018; Golebiewska et al., 2020; Rodríguez, 2019) emphasize that the prerequisites for sustainable agricultural development in the environmental sense are created when farms are able to preserve and restore natural resources (soil, diversity of biological species, essential ecosystems and ecological processes) consumed in the production process.

Social aspect of sustainability is linked to a commitment to meet society's needs by ensuring a better quality of life. This includes education, working conditions and workers' well-being, community and regional development, consumer health and safety, human rights and child labour, and other social issues. The prerequisites for the sustainable development of agriculture in a social sense are created when rural communities are preserved and close social relations are maintained (Sulewski et al., 2018; Vilkè et al., 2020; Jarrett et al., 2015; Wilson, 2017). Sulewski et al. (2018) note that social sustainability is most often measured by education, experience and skills in farming, family's social status, decision-making methods, living conditions, involvement in community problems, security, etc.

On the basis of general environmental, social and economic objectives of sustainable agriculture, it can be stated that agriculture is considered sustainable when it is able to remain economically viable, environmentally sound and socially equitable for a long period of time (Wilson, 2017, Sulewski et al., 2018, Čiegis, 2009, Dania et al., 2018, Golebiewska et al., 2020; Rodríguez, 2019 and others). It is clear that the development of sustainable agriculture must be the responsibility of all participants of the agricultural system: farmers, processors, traders, government representatives and consumers themselves. Meanwhile, other authors added that a need arises for active collaboration with the scientific community in order to achieve sustainable agriculture and reduce negative environmental impacts. In the absence of such collaboration, sustainability efforts are at risk of failing by adopting unrealistic goals or forming a wrong approach. According to the statements of the authors (Šumane et al, 2018), „knowledge networking and multi-actor knowledge networks that facilitate knowledge exchanges, joint learning and the generation of new more integrated solutions, are crucial if agriculture is to become sustainable" (p. 232). This statement is supported by other scientists (Thomson et al., 2017), arguing for a dialogue between scientists, farmers and private sector stakeholders in order to gain scientific knowledge and promote the overall objective of sustainable agricultural development.

This debate of scientists highlights the importance of promoting collaboration. It can be stated that modern policy of sustainable agricultural development, oriented towards the sustainable implementation of economic, social and environmental dimensions, cannot exist without more active involvement and collaboration of stakeholders, which is understood as the foundation for sustainable development of agricultural and food production.

\subsection{The Importance of Collaboration for Sustainable Agriculture Development}

In the scientific literature, the concept of collaboration is widely studied by various authors, most commonly, collaboration refers to organizations or companies working together to reach particular objectives, and is identified as a way to maintain relationships and communicate. It has been noted that the terms "collaboration" and "cooperation" are often used interchangeably to describe any actions whereby farmers are working together to achieve either a common goal or to gain mutual benefits. However, Wilson (2017) points out that "collaboration most frequently refers to collective or joint action that provides an environmental benefit" (p. 8). By collaborating, organisations strive for the common good, participate in collective actions for the common good and promote the process of collaboration. The scientific literature recognises that effective collaboration is based on the sharing of information and joint decision-making, sharing of risks and rewards, services and resources, which promotes mutual trust and a sense of belonging to the collaboration system, which encourages the parties concerned to contribute as much as possible to the sustainable development of agriculture.

According to Velten et al. (2015), "addressing sustainability problems in agriculture often goes beyond technical fixes and requires systemic change, which includes changes in organisations, 
behaviour, and kinds of relations among stakeholders. For fostering such systemic innovations, collaboration is a key factor" (p.p.5). In order to achieve sustainable agriculture, many stakeholders can be distinguished through collaboration, including farmers, food producers, distributors, retailers, consumers, government, NGOs, etc. The resources and/or capacities of many stakeholders involved in this collaboration are very limited and they must carefully choose collaboration initiatives in which they will invest their time and money. Very often, collaboration initiatives are doomed to fail because the needed players do not have motivation to participate and to tackle the difficulties encountered due to lack of experience or other factors (Miller and McCole, 2014).

Today, collaboration between farmers in order to improve environmental protection should be a key issue in managing a sustainable supply chain. In most cases, collaboration in the supply chain is a common phenomenon, where companies share information and build strategic alliances, in order not only to reduce overall costs but also to contribute to the development of sustainability. However, this phenomenon is not so obvious in agriculture in terms of sustainability. According to the statements of scientists (Schiefer et al. 2015; Bélanger et al., 2012; Dania et al., 2018; Prager, 2015; Thomson et al., 2017; Vilkè et al., 2020) collaboration is essential for the development and development of innovative ideas and their application in practice and is linked to the social, economic and ecological sustainability of the agricultural and food system. Recent studies (Azevedo et al., 2018; Ding et al., 2018; Vachon and Klassen, 2008; Prager, 2015) revealed several important synergies between collaboration and sustainability, such as cleaner production, sustainable consumption, adaptation of environmental technologies and sustainability management.

The provision of agricultural services and the pursuit of sustainable agriculture clearly require active collaboration between farmers, e.g., sharing resources, machinery or work (buying or selling services), offers many opportunities: it helps to reduce costs, increase profits, ensure the quality of activities and products and, as a result, gain consumer confidence. Lorencowicz et al. (2013) research revealed that "the most important factor in favour of collaboration was lack of one's own equipment and, in case of elderly farmers, the limited possibility of their own work. Despite relatively low economic gain and frequent use of non-monetary forms of settlements, the farmers' collaboration practiced throughout the years afforded proper operation of the farms and protected their owners in case of lack of technical means" (p.p.142).

Most authors (Velten et al., 2021; Dania et al., 2018; Hubeau et al., 2017; Ding et al., 2018; and others) agree that in order to achieve the development of sustainable agriculture, farmers need to collaborate, by sharing their assets - materials, labour, infrastructure, devices and equipment and machinery; and their capabilities - technologies, business processes, policy and finance.

According to Dania et al. (2018), farmers with limited labour resources or financial opportunities to acquire and use technologically advanced and sustainable farming devices, equipment or machinery could cooperate in harvesting by sharing both labour and machinery. Başarik et al. (2015) state, that purchasing technologically advanced farm machinery or device for farmers are very expensive. Collaboration by sharing farm machinery could help farmers not only to decrease their equipment investment and operating expenses but also to enable more efficient use of land resources, improve crop rotations, to reduce greenhouse gas emissions. Lorencowicz et al. (2013) note, that farmers' collaboration, in terms of sharing resources, machinery or work, buying or selling services, allows the farms to fulfil the requirements for sustainable agriculture development, at the same time, the quality of life for farm families.

Therefore, economic operators can reduce uncertainty, share risks and costs, serve customers at the right time, in the right quantity and in the right quality, thus contributing to the sustainable development of agriculture only through collaboration (Dania, et al., 2016; Ding et al., 2018; Prager, 2015; Azevedo et al., 2018).

The scientific community is actively discussing what factors can influence farmers' collaboration initiatives. The studies show that companies prefer to collaborate with an organization with similar size, structure, capabilities and resources (Dania et al., 2016; Bourlakis et al., 2014). Wilson et al. (2014) note that the main drivers and obstacles to collaboration include issues of personal goals, experiences and values, which can be influenced by education, the impact of information 
and the age of the farmer. In addition to obstacles to the success of collaboration, Wilson et al. (2016) identify the lack of communication and mutual understanding, the farmer's desire to be independent, attitude to risk, especially when sharing equipment and machinery. „Collaboration relies on trust and social capital, which does not exist everywhere to the same extent" (Prager, 2015 p. 63). According to Schiefer et al. (2015), Blome et al. (2014), Hudnurkar et al. (2014), trust, reciprocity, information exchange, openness and communication are key elements that reflect the perspective of collaboration. Bezuidenhout et al., (2012) highlight that trust, commitment and willingness to share risks become the basis for the long-term goal of strong cooperation. Stability, reliability and trust are three critical components that have mutual influence: stability will create reliability, and reliability - trust. Dania et.al. (2016, 2018), Panahifar et al. (2018), also highlight that trust is key aspect not only to effective collaboration, but also to improving sustainability indicators. In this approach, trust is essential for understanding the behaviour of individuals and how they relate to each other when implementing collaboration initiatives in the context of coherence. Other authors argue that sufficient technology and information are needed to maintain effective collaboration. In addition, the willingness of both parties to commit to positive collaboration is needed to build mutual trust between partners (Rota et al., 2013). Hubeau et al. (2017) studies identified as many as 13 key factors of collaboration success, namely „asset specificity, intensity of control, risk sharing, relevance of identify, length of relationships, trust, power, allocation of decision rights, frequency of interaction, information exchange, quality of communication, expected social gains, and motivation" (19 p.).

Based on the systematic literature analysis, the authors of this paper present a theoretical conceptual model, which illustrates the perspectives of farmers' collaboration developing sustainable agriculture (see Fig. 1).

The development of sustainable agriculture can be assessed through economic, environmental and social dimensions. The key to more sustainable agriculture is farmers' collaboration by sharing their assets and opportunities, which can help to reduce resources and handling costs, uncertainty, risks, effectively serve customers, and fulfil the requirements for sustainable agriculture development. In summarizing, it can be stated that a prerequisite for active collaboration between farmers in the context of sustainability is the need to address mistrust, quality of communication, mutual understanding, attitudes towards sharing risks, the openness of information and other issues.

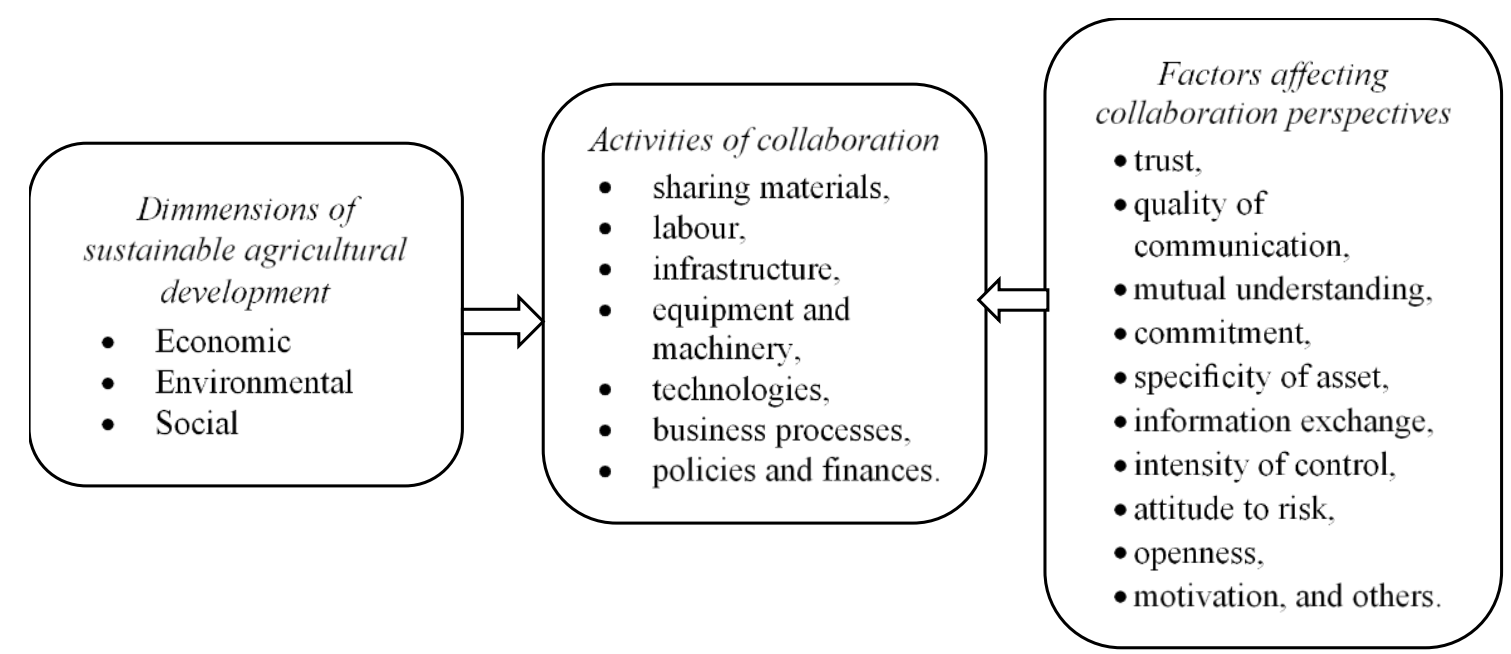

Fig 1. Theoretical conceptual model illustrating the perspectives of farmers' collaboration developing sustainable agriculture. 


\section{Research Methodology}

Analysis of the scientific literature has revealed that collaboration between farmers is one of the most important ways to develop sustainable agriculture (Velten et al., 2021; Vilke et al., 2020; Wike et al., 2018; Azevedo et al., 2018; Ding et al., 2018, and others). The study, therefore, seeks to clarify collaboration initiatives among Lithuanian farmers and the factors affecting collaboration in order to achieve sustainable agriculture development.

A combination of qualitative and quantitative research methods was used to conduct the study. A qualitative study using a semi-structured interview was used to explore how collaboration is understood in the context of sustainable agriculture, to analyse farmers' collaboration practices and to identify opportunities for increasing collaboration in the development of sustainable agriculture. A semi-structured interview was conducted with 7 Lithuanian farmers who voluntarily agreed to participate in the study. In order to preserve anonymity, informants were encoded $\left(I_{n}\right)$. Interviews took place on farms where interviewers work. Each interview took about 30-40 minutes, the answers recorded in writing. The research was carried out in August-September 2020. The response data obtained were analysed using a qualitative content analysis method, revealing the relevance of the problem being analysed.

A quantitative study, using a questionnaire written survey, is intended to find out the collaboration needs of Lithuanian agricultural entities to share works and machinery, i.e., purchase/provision of agricultural services, reasons for not buying or providing them. Based on the insights of the researchers presented in the theoretical part (Velten et al., 2021; Dania et al., 2018; Başarik et al., 2015; Ding et al., 2018; Lorencowicz et al., 2013) in this research, sharing of works, machinery and information are recognized as a precondition for sustainable agricultural development. The study involved Lithuanian agricultural operators (farmers, agricultural companies). The questionnaire consisted of 17 questions, 5 of which were intended to identify socio-economic characteristics of agricultural operators, and 12 questions were intended to identify respondents' behaviour and incentives in purchasing/providing agricultural services, sharing machinery and information, and reasons. Participants were recruited using the "snowball" method, using a network of researchers' colleagues and acquaintances. Data was collected through printed questionnaires, as well as through the internet, using the website "Manoapklausa.It". In August-October 2020, a total of 130 questionnaires were collected, 124 of which were duly completed and suitable for further analysis.

Quantitative survey studies allowed to determine the frequency of recurrence of signs and perform their statistical analysis using the Microsoft Excel program. A correlation analysis was used to assess the relationship between farmers' self-determination, intentions and incentives in the market of agricultural services and the factors of the farmer's age, experience and resource availability. To reveal quantitative data interfaces, the Pearson correlation coefficient (denoted by r) was used, i.e., the covariance of the two variables is divided by the product of their standard deviations. In the study, the Excel CORREL function was used to set $r$. Indicators of farmers' age, experience and resource availability were given in a range value, while average values of the ranges were used for the calculation of $\boldsymbol{r}$.

The ratio of the correlation coefficient to its error (denoted $s_{r}$ ), which is a criterion for the statistical reliability of the correlation relationship (denoted $t$ ), assesses whether this relationship is statistically significant, reliable or not at a given degree of accuracy (usually $5 \%$, which corresponds to $95 \%$ of probability; denoted $\alpha=0,05)$. The work was not limited to five percent accuracy, a slightly lower, 6,7 and 8 percent (94, 93 and $92 \%$ of probabilities), was allowed as well.

In the correlation analysis, the pair of subjects whose reliability of relationship indicator $t$ exceeds

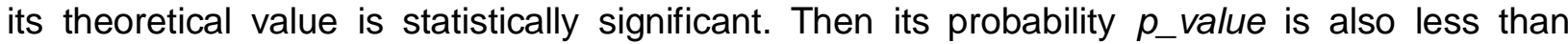
the chosen accuracy $\alpha$. For reliability $t$, the following formula was used:

$$
t=\mathrm{r} \cdot \sqrt{1-\mathrm{r}^{2}} / \sqrt{\mathrm{n}-2},
$$


where: $r$ is the Pearson correlation coefficient; $n$ is the sample size, which is different in each case of the interface under investigation. The size in the formula after the multiple mark is the tolerance of the coefficient $r$. The Excel function T.DIST.2T ( $\mathrm{t} ; \mathrm{n}-2)$ used to calculate the probability $p \_v a l u e$.

\section{Research results}

The aim of the qualitative study was to find out perception of Lithuanian farmers' on the concept of collaboration in the context of sustainable agricultural development, their collaboration practices and to identify opportunities for increasing collaboration in the development of sustainable agriculture. Table 1 presents the opinion of the informants in the analysis of Lithuanian farmers' knowledge about collaboration in the context of sustainable agriculture. The analysis of informants' responses identified three subcategories: 1) importance of sustainable agricultural development, 2) concept of collaboration and 3) benefits of cooperation.

In the course of the scientific literature analysis, it was found that sustainable agriculture and its development, combining economic, social and environmental measures, are a topical issue today all around the world. In striving for development of sustainable agriculture, an important role is being played by active collaboration between stakeholders that brings various benefits to the collaborating sides. The studies conducted by our team confirmed these results in most cases. Having analysed the statements of informants, it became clear that their understanding of the concept of collaboration for the sustainable development of agriculture in Lithuania is sufficient (see Table 1). The informants highlight the need for land, renewable resources and energy saving, environmental pollution reduction, food quality and population health conservation, which reveals an awareness of the importance of sustainable agricultural development. The informants emphasize that collaboration includes aspects such as joint actions, communication, sharing of information, knowledge, experience and equipment, machinery, materials and labour. The participants are confident that common objectives and actions between stakeholders are the basis for the sustainable development of farming. In their opinion, the benefits of collaboration are higher quality production, higher consumer trust, higher incomes, better capacity utilisation, as well as cost savings.

Tab 1. Perception of collaboration concept in the context of sustainable agricultural development.

\begin{tabular}{|c|c|c|}
\hline Category & Subcategory & Confirmatory statements \\
\hline $\begin{array}{l}\text { Knowledge of } \\
\text { collaboration in } \\
\text { the context of } \\
\text { sustainable }\end{array}$ & $\begin{array}{l}\text { Importance of } \\
\text { sustainable } \\
\text { agricultural } \\
\text { development }\end{array}$ & $\begin{array}{l}\text { „...it is necessary to conserve and not to exploit renewable } \\
\text { resources and use energy resources as sparingly as possible, } \\
\text { because we will exhaust the earth"(I1) } \\
\text { "If a farmer does not take care of the land responsibly, the land } \\
\text { will not provide a healthy raw material for food, the financial } \\
\text { situation will deteriorate and workers and consumers will be } \\
\text { unsatisfied... "(I2) } \\
\text { „...farmers should commit to moderate or no use of chemicals, } \\
\text { which will lead to less pollution of the environment, groundwater, } \\
\text { and finally, to healthier food products, satisfied consumers" (I3) } \\
\text { „... we do organic farming with the understanding that it } \\
\text { significantly affects our quality of life today, tomorrow and future } \\
\text { generations" (I4). } \\
\text { "...our moral obligation to provide consumers with food not only } \\
\text { at reasonable prices, but to ensure the highest standards of } \\
\text { animal health, quality and well-being“(I5) } \\
\text { „sustainable farming is a rather difficult task, but it is very topical, } \\
\text { and quality of food and health of the population, and our own } \\
\text { financial situation, depend on it..."(I6) } \\
\text { "we apply the principles of sustainable agriculture to our farm, } \\
\text { understanding the importance of maintaining a clean } \\
\text { environment ... we need to ensure that our children grow up in } \\
\text { a clean environment“(I7) }\end{array}$ \\
\hline
\end{tabular}




\begin{tabular}{|c|c|}
\hline Subcategory & Confirmatory statements \\
\hline $\begin{array}{l}\text { Collaboration } \\
\text { concept }\end{array}$ & 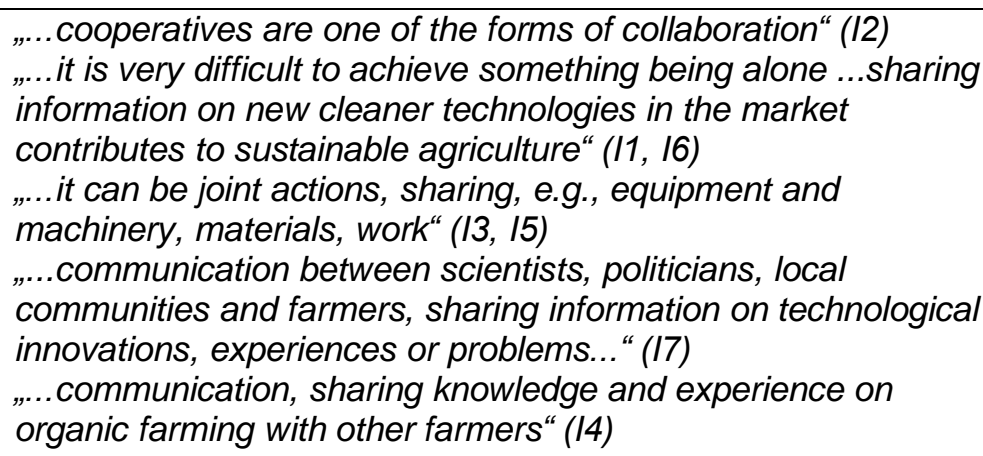 \\
\hline $\begin{array}{l}\text { Benefits of } \\
\text { collaboration }\end{array}$ & $\begin{array}{l}\text { "This would save financial costs, e.g., while sharing machinery, } \\
\text { labour force..."(I1, I3) } \\
\text { „....common objectives and actions among stakeholders are } \\
\text { the basis for the sustainable development of farming..."(I4) } \\
\text { "Higher quality production, higher consumer trust, higher } \\
\text { incomes..."(I6) } \\
\text { "Better use of available capacity, better quality and faster } \\
\text { work..."(I2) }\end{array}$ \\
\hline
\end{tabular}

This study also sought to clarify the practice of collaboration among Lithuanian farmers and to identify opportunities for increasing collaboration in the development of sustainable agriculture. While analysing the interview study material, three categories were observed: 1) reasons for collaboration, 2) reasons for non-collaboration, and 3) possibilities for increasing collaboration. The results are presented in Table 2.

Tab 2. Collaboration practices between farmers in the development of sustainable agriculture.

\begin{tabular}{|c|c|c|}
\hline Category & Subcategory & Confirmatory statements \\
\hline $\begin{array}{l}\text { Collaboration } \\
\text { motives }\end{array}$ & $\begin{array}{l}\text { Lack of machinery } \\
\text { Dispersion of good } \\
\text { practice } \\
\text { Capacity utilisation }\end{array}$ & $\begin{array}{l}\text { „...I am running out of machinery at harvest time and } \\
\text { other farmers are helping... (I1, I6) } \\
\text { „we are happy to share our knowledge and experience } \\
\text { of organic farming with other farmers, hold meetings" } \\
\text { (I4) } \\
\text { "I always offer my services to use the most of capacity of } \\
\text { the available equipment, ... and it is beneficial to me and } \\
\text { to others too, saves money and time" (I5) }\end{array}$ \\
\hline $\begin{array}{l}\text { Reasons for non- } \\
\text { collaboration }\end{array}$ & $\begin{array}{l}\text { Lack of information } \\
\text { Distrust } \\
\text { Risk }\end{array}$ & $\begin{array}{l}\text { "I have a lot of modern and expensive machinery } \\
\text {... could offer, but no one comes to me, and I don't } \\
\text { know where to go either" (I2) } \\
\text { "... I do not trust others, quality of work, besides I do not } \\
\text { want to be dependent on others (I3) } \\
\text { "There is a risk of machinery damage which is very } \\
\text { expensive, so I do not offer to collaborate..." (I7) }\end{array}$ \\
\hline $\begin{array}{l}\text { Possibilities to } \\
\text { increase } \\
\text { collaboration }\end{array}$ & $\begin{array}{l}\text { Sharing experience, } \\
\text { knowledge and } \\
\text { information }\end{array}$ & $\begin{array}{l}\text { „I would also encourage other farmers to share their } \\
\text { organic farming experience and knowledge more } \\
\text { actively" (I4) } \\
\text { "To create an information portal where news, } \\
\text { achievements and best sustainable agriculture } \\
\text { practices, feedback, should be published, a trust would } \\
\text { be higher...(I1) } \\
\text { "To organize meetings or seminars, share information, } \\
\text { make contacts..."(I6) } \\
\text {,... p platform could be created where farmers would } \\
\text { provide information to others about the available unused } \\
\text { labour or technical capacity, to the benefit of both } \\
\text { sides...(I2) }\end{array}$ \\
\hline
\end{tabular}


According to the responses of the informants in Table 2, it was observed that although Lithuanian farmers are collaborating seeking sustainable agriculture development, collaboration practices are not developed sufficiently. According to the informants, there is a collaboration in case of technical shortage during harvest, in order to exploit the capacity of the equipment and to share best practices on organic farming. These results are consistent with collaboration practices identified in the scientific literature. However, other informants distinguished the main reasons for non-collaboration, which also coincide with obstacles such as lack of information, distrust in the quality of work and desire to be independent, fear of risk sharing machinery identified in the scientific literature (Wilson et al., 2016; Prager, 2015; Panahifar et al., 2018). The study also revealed the opinions of informants on the possibilities for increasing collaboration in the context of sustainability. According to the statements of informants, there is a need to increase the sharing of experience, knowledge and information by organising meetings or seminars and setting up an information portal or platform. These measures can ensure better communication, exchange of information, mutual trust and reduce risks, thus leading to the sustainable development of agriculture.

A quantitative study sought to clarify the collaboration needs of Lithuanian agricultural entities to share work and machinery. Analysing the regularities of the behaviour and incentives of agricultural operators in the agricultural services market in relation to the factors of the farmer's age, experience and resource availability, correlation $r$, reliability $t$ and probability of reliability p_value of all possible pairs of cases, have been identified. The interfaces for which p_value is less than $0.05,0.06,0.07$ and 0.08 , corresponding to probabilities of $0.95,0.96,0.97$ and $0.98 \%$, are considered statistically significant. The study proved that certain cases of behaviour and incentives of agricultural operators, mainly farmers in the agricultural services market, correlate significantly with the farmer's age, work experience and the extent to which a self-propelled machinery is supplied. The remaining resource availability factors, such as the number of farm workers and the size of the land holding, were rejected as "not passing" the statistical significance test. A Scatter-type diagram was used to reveal causal regularities.

Table 3 shows the links between farmers' decision to collaborate - to buy, sell agricultural services, share information online - and the farmer's age, work experience and size of resources, based on Pearson $r$ and $p_{-}$value. Statistically significant correlations are marked with an asterisk.

Tab 3. Pearson $r$ and p_value when purchase and sale of farmers' services are influenced by social / economic factors.

\begin{tabular}{|c|c|c|c|c|c|c|c|c|c|c|c|c|}
\hline \multirow{2}{*}{$\begin{array}{c}\text { Decision } \boldsymbol{r} \\
\text { depending on: }\end{array}$} & \multicolumn{4}{|c|}{$\begin{array}{c}\text { Purchase of service } \\
\qquad / \boldsymbol{p} \text { _value }\end{array}$} & \multicolumn{4}{|c|}{$\begin{array}{c}\text { Provision of service } \\
\qquad \boldsymbol{r} / \boldsymbol{p}_{\text {_ value }}\end{array}$} & \multicolumn{4}{|c|}{$\begin{array}{l}\text { Provision of online } \\
\text { information } \\
\text { www } r / p_{\text {_value }}\end{array}$} \\
\hline & a & b & $C$ & d & $a$ & $b$ & C & d & $a$ & $b$ & C & d \\
\hline \multirow{3}{*}{$\begin{array}{l}\text { Farmer's age } \\
\text { Farmer's work } \\
\text { experience }\end{array}$} & & & & & & & & & & & & \\
\hline & & & & & & & & & $-0.91^{\star}$ & $-0.84^{*}$ & 7 & \\
\hline & & & & & & & & & & 0. & & . \\
\hline \multirow{3}{*}{$\begin{array}{l}\text { Holding size } \\
\text { Number of } \\
\text { employees on } \\
\text { the farm } \\
\text { Provision of } \\
\text { machinery }\end{array}$} & $\begin{array}{l}0.13 \\
0.77\end{array}$ & $\begin{array}{r}-0.32 \\
0.45\end{array}$ & & & $\begin{array}{r}-0.34 \\
0.40\end{array}$ & 0.4 & & & $\begin{array}{r}-0.43 \\
0.28\end{array}$ & $\begin{array}{r}-0.21 \\
0.61\end{array}$ & $\begin{array}{l}0.18 \\
0.70\end{array}$ & 0.42 \\
\hline & $\begin{array}{c}-0 . \\
0 .\end{array}$ & 0.24 & 0.1 & $\begin{array}{r}-0.48 \\
0.27\end{array}$ & $\begin{array}{r}-0.53 \\
0.23\end{array}$ & & & & $\begin{array}{r}-0.58 \\
0.17\end{array}$ & $\begin{array}{r}-0.48 \\
0.27\end{array}$ & $\begin{array}{r}-0.28 \\
0.66\end{array}$ & 0.21 \\
\hline & $\begin{array}{r}-0.87 \\
0.13 \\
\end{array}$ & $\begin{array}{r}-0.87 \\
0.13 \\
\end{array}$ & $\begin{array}{r}-0.93^{\star} \\
0.07 \\
\end{array}$ & \begin{tabular}{r|}
-0.82 \\
0.18 \\
\end{tabular} & $\begin{array}{r}-0.83 \\
0.17 \\
\end{array}$ & $\begin{array}{r}-0.94^{*} \\
0.06 \\
\end{array}$ & $\begin{array}{r}-0.96^{\star} \\
0.04 \\
\end{array}$ & \begin{tabular}{r|}
-0.83 \\
0.17 \\
\end{tabular} & $\begin{array}{r}-0.94^{\star} \\
0.06 \\
\end{array}$ & $\begin{array}{r}-0.84 \\
0.16 \\
\end{array}$ & $\begin{array}{r}-0.61 \\
0.15 \\
\end{array}$ & 0.1 \\
\hline
\end{tabular}

Markings: a - yes, regularly, b-yes, sometimes, c - no, but intends, $\mathrm{d}-$ no, and doesn't intend

The identified dependencies are largely non-essential ( $p \_$value $>0.05 \div 0.07$ ). What is "encrypted" with an asterisk in the table is statistically significant dependencies, to be named and explained as follows:

- dependence of the age of farmers and the non-purchase of agricultural services $(r=0.93$, p_value $=0.02$ ): the older the farmers, the less they buy and tend to buy agricultural services (see 
Fig. 2, Age: the regularities of buying and selling almost coincide here). Usually, older farmers more often express dissatisfaction with the performance of services and as a reason indicate the fact that they are performed at the wrong time. Actually, the desire to be independent is more often inherent also in older farmers. They are more likely not to see economic benefits because they think the cost of services is excessive;

- dependence of farmers' age and non-provision of agricultural services $\left(r=0.98, p \_v a l u e=\right.$ 0.004 ): older farmers provide less and less tend to provide services (see Fig.1). To explain why, it can be said that older farmers are more likely to have no time for this, especially during the season;

- dependence of farmers' work experience and use of the internet $\left(r=-0.91, p \_v a l u e=\right.$ 0.03 and $r=-0.84$, p_value $=0.07$ ): the greater the experience of farming, the less use is made of the internet for the sale of agricultural services (Fig.2, trend line 1). Typically, greater farming experience is accompanied by a correspondingly higher age. Older people are less daring in the online space;

- dependence of farmers' self-supply in machinery and non-purchase of agricultural services $(r=-0.93$, p_value $=0.07)$ : the more their own self-propelled machinery farms have, the less they buy and tend to buy agricultural (Fig. 2, trend line 1). It is clear that the purchase of services is not relevant when the farmer can do agricultural work with his own self-propelled machinery;

- dependence of farmers' self-supply in machinery and (non)-providing of agricultural services $\left(r=-0.94\right.$, p_value $=0.06 ; r=-0.96$, $p \_$value $\left.=0.04 ;\right)$ : the more supply of self-propelled machinery is in the farms, the less often they provide or intend to provide agricultural services (Fig. 2, trend lines 2 and 4 );

- dependence of farmers' supply in machinery and use of the internet $\left(r=-0.98, p \_v a l u e=\right.$ $0.02 ; r=-0.94$, p_value $=0.06$ ): the more machinery farms have, the less they use the internet to buy and sell agricultural services (Fig. 2, trend lines 3 and 5).

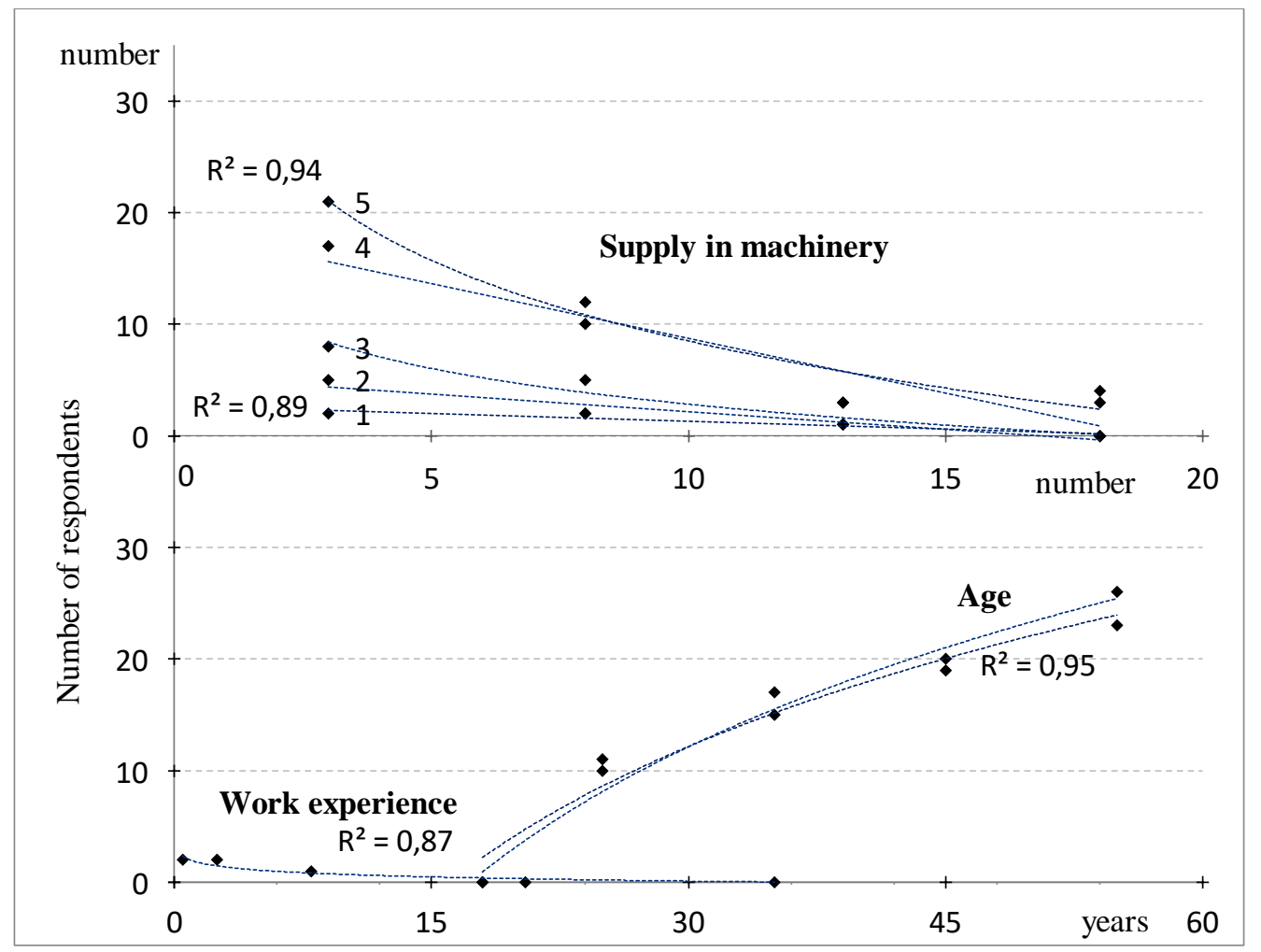

Fig 2. Statistically significant regularities in farmers' willingness to collaborate in the market of agricultural services. 
In conclusion, it can be stated that as the age of the farmer increases, the slackness and demotivation to buy and offer agricultural services increase. Motivation to buy and the need to use e-sources in the provision/offering of agricultural services diminish as the farmer's work experience increases. As the supply in self-propelled machinery of the farm increases, motivation to purchase or offer agricultural services increases, and a need to use e-sources for the purchase and delivery of agricultural services weakens.

It was determined that as many as $67 \%$ of respondents (especially younger farmers) are reluctant to cooperate (e.g., buy or sell production, provide agricultural services to other farmers, etc.).

A decision to buy or not to buy services depends largely on the size of the farm holding - the larger the size of the farm holding, the more often they tend to buy services. This can be explained by the fact that larger farms have a large variety of crops and therefore it is not possible to own some specialised machinery.

The decision to purchase or not the services depends on the farm's supply in machinery. It was considered that farmers who do not own necessary agricultural machinery or who do not have qualified workers on the farm should be more likely to purchase services. However, it has emerged that those farmers who have more of their own machinery are more likely to buy services. This contradiction is explained by the lack of specialized machinery on larger farms.

The respondents differently explained their attitude towards non-purchase of services (see Fig. 3).

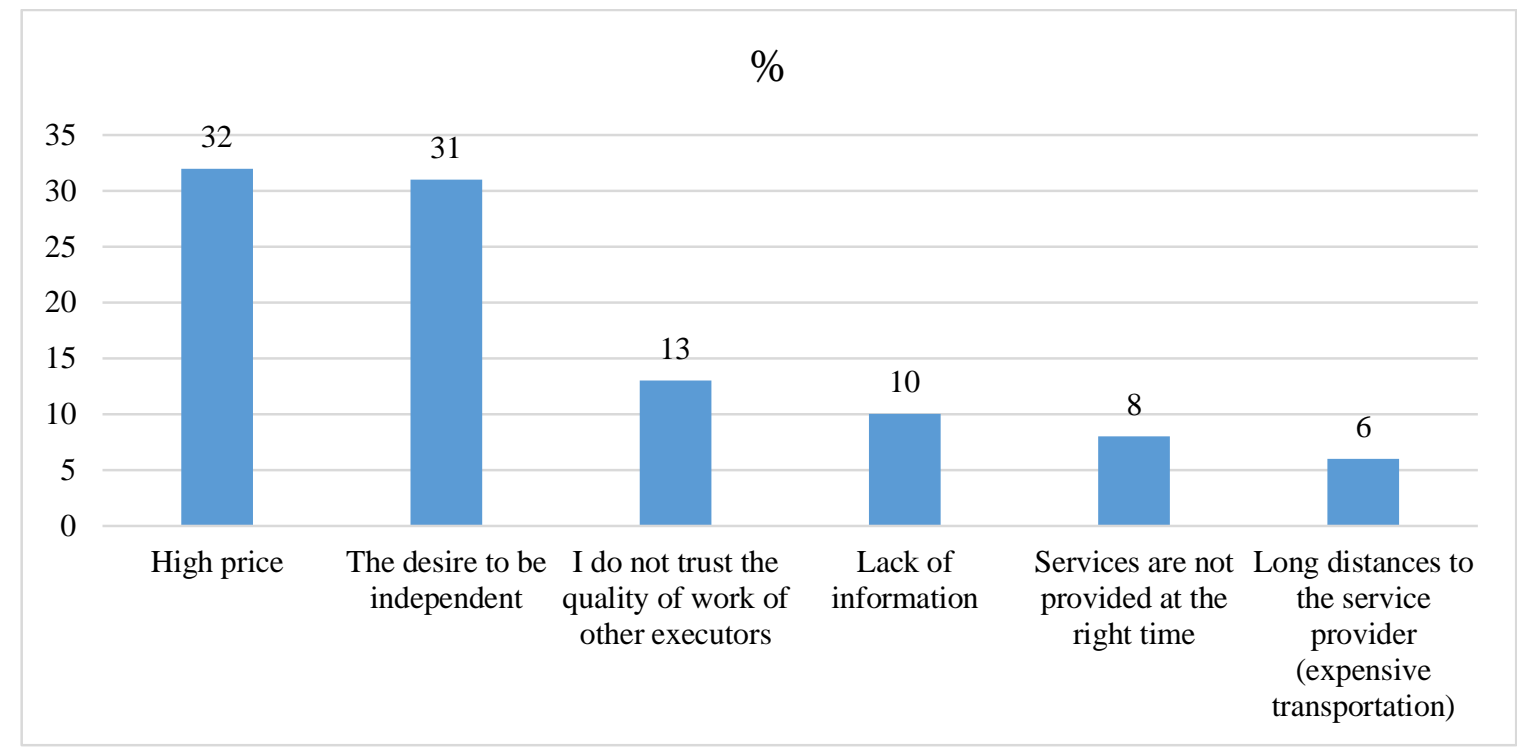

Fig 3. Reasons for not buying agricultural services, in percent.

The main reason is that about a third of farmers (about $32 \%$ ) considers that the cost of services is too high and therefore they see no economic benefits. In the course of the survey, farmers were asked whether this claim was valid or whether they had calculated the "economic benefits" of working with your own machines and the services they purchased. The answers were unambiguous that the cost of works is not calculated, because it is complex, and there is no convenient and simple spreadsheet.

A significant proportion of farmers replied that they did not buy services because they wanted to be independent, while others questioned the quality of the services $(13 \%)$ and whether services will be carried out at the right time (8\%). A big proportion of farmers $(10 \%)$ do not buy services because they do not know service providers, i.e., they do not know how to find them. The lack of information on service providers and those wishing to receive services is therefore a serious reason for insufficient collaboration. There are other reasons for limiting the purchase of services $(6 \%)$ as well: long distances, the farm has sufficient number of its own machineries, the machines are not interconnected and therefore impossible to complete the aggregate, the necessity of paying taxes, etc. 
The respondents also differently explained their position on the non-provision of services to other farmers (see Fig. 4).

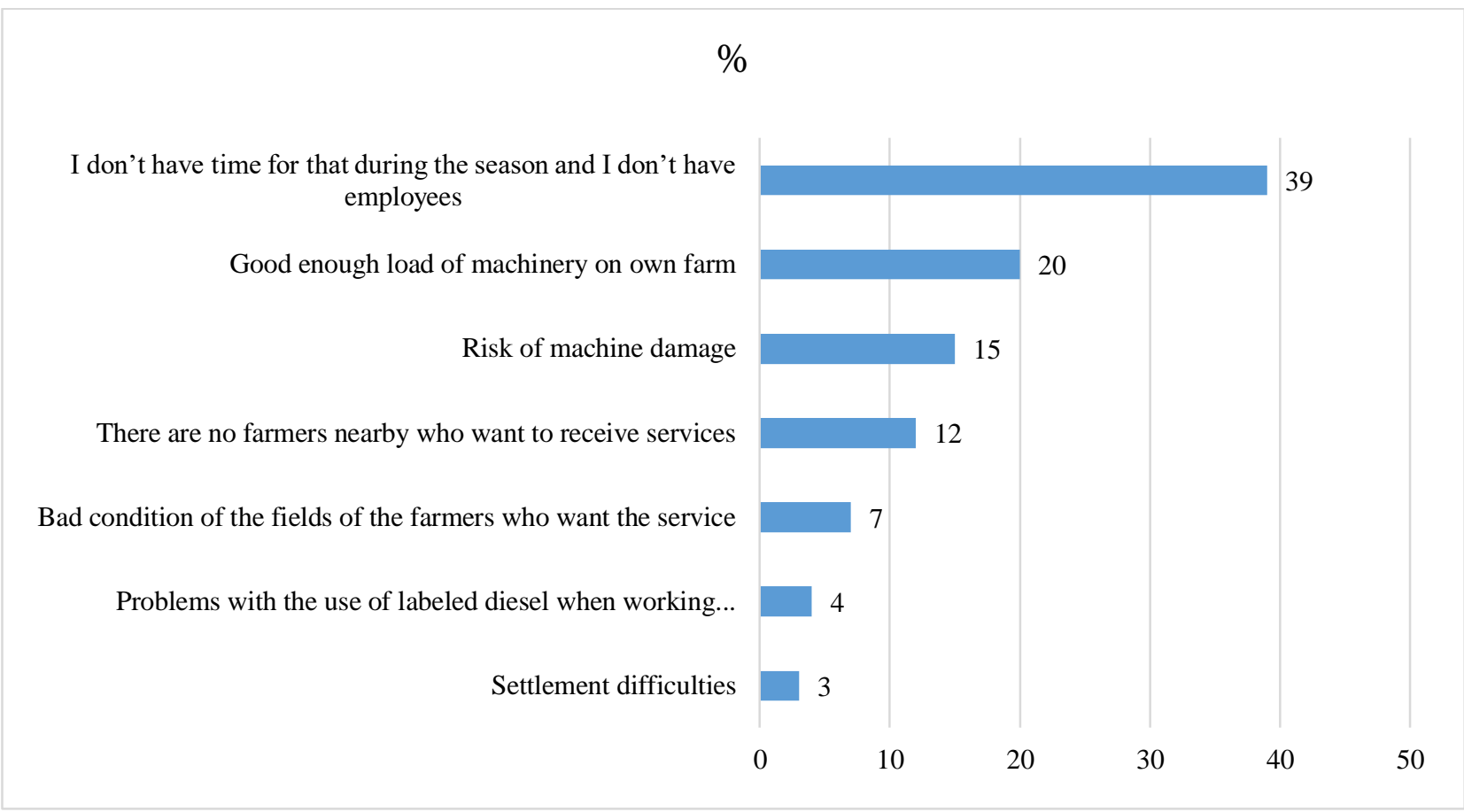

Fig 4. Reasons for not providing agricultural services, in percent.

Most farmers (about 40 percent) cannot work on their own during the season because they do not have time and they do not have hired workers. In addition, a significant proportion of respondents $(22 \%)$ are afraid to damage machinery because they believe that fields of the farmers who want to receive services are in bad condition, and others (20\%) replied that there is a good enough load of machinery on their own farm. Other reasons, although having a lower comparative weight, are quite important. Some respondents replied that they do not provide services because they find it difficult to find those who want to buy them.

\section{Conclusions}

The development of sustainable agriculture is one of the greatest challenges of the $21^{\text {st }}$ century, obliging all stakeholders to look for effective solutions. Sustainable agriculture is defined as sustainable production that is consistent with optimal management of natural resources, their protection and the effective implementation of institutional and technological change in agriculture, taking into account the needs of current and future generations. Analysis of the scientific literature (Dania et al., 2018; Azevedo et al., 2018; Ding et al., 2018; Thomson et al., 2017; Vilkè ir kt., 2020; Sulewski ir kt., 2018, and others) has shown that the concept of sustainable agricultural development combines economic, environmental and social aspects (Golebiewska et al., 2020; Wilson, 2017; Rodríguez, 2019; Sulewski et al., 2018, and others.), in which agriculture is able to maintain itself in a long-term economic perspective, safe for the environment and socially equitable (Vilkè et al., 2020; Čiegis, 2009, and others.).

The scientific debate recognises the role of collaboration as an important way of implementing the principles of sustainable agriculture and is particularly important in its potential to address the competitiveness, risks, costs, incomes and other relevant issues of agricultural products (Ding et al., 2018; Prager, 2015; Azevedo et al., 2018; and others). Through collaboration, agricultural operators have the opportunity to share their assets - materials, labour, infrastructure, equipment and devices and machinery; and their opportunities - technologies, business processes, policies and finances. Only active collaboration between stakeholders can reduce uncertainty, share risks and costs, serve customers at the right time, in the right quantity and in the right quality, thus contributing to the sustainable development of agriculture. A prerequisite for active collaboration 
between farmers in the context of sustainability is the need to solve the problems of mistrust, the quality of communication, mutual understanding, risk attitudes, openness of information and other (Dania et al., 2018; Hubeau et al., 2017; Wilson et al., 2016; Schiefer et al., 2015; Bezuidenhout et al., 2012, and others).

The results of qualitative and quantitative studies confirmed the insights from the analysis of the scientific literature (Dania et al., 2018; Prager, 2015; Jarrett, 2015; Sutherland et al., 2015, and others) that collaboration is a very important condition for the development of sustainable agriculture. The interview study revealed that common goals and actions among stakeholders are the basis for the sustainable development of farming. The benefits of collaboration are better production, higher consumer trust, higher incomes, better capacity utilisation, as well as cost savings. However, despite collaboration in the event of technical shortage, in striving to exploit the capacity of the equipment and to share good practice on organic farming, collaboration practices among Lithuanian farmers are not developed sufficiently. Lack of information, distrust in the quality of work, the desire to be independent, the fear of risk in machinery sharing are the main obstacles to active collaboration. These obstacles have also been identified by other authors in their studies before (e.g., Wilson et al., 2016; Panahifar et al., 2018; Schiefer et al. 2015).

A quantitative study has shown that although inter-farm collaboration through the sharing of machinery leads to higher employment of machinery, at present a very small number of farmers provide agricultural services to other farmers and use the services of other farmers. Such research results allow us to conclude that Lithuanian farmers have little response to the condition that the sharing of work and machinery is an important precondition for sustainable agricultural development. Older owners of larger agricultural holdings and machinery are more likely to provide agricultural services to other farmers and to use the services of other farmers than young owners of smaller agricultural holdings and machinery. One reason for insufficient collaboration is the lack of information on service providers and those wishing to receive services. Another reason for insufficient collaboration is that farmers do not currently see (because they do not count) the benefits of providing and obtaining services, because there is not enough simple methodology for calculating the economic benefits. Summarizing the results of the study, it can be noted that more active collaboration requires more active sharing of experience, knowledge and information through meetings or seminars by creating an information portal or platform. These measures could lead to more qualitative communication, more open information sharing, mutual trust and risk reduction, which would ensure the development of sustainable agriculture.

\section{Academic references}

[1] Azevedo, S. G., Silva, E. M., Matias, C. O. J. \& Dias, P. G. (2018). The Influence of Collaboration Initiatives on the Sustainability of the Cashew Supply Chain. Sustainability, 10, 2075. DOI: 10.3390/su10062075.

[2] Başarık, A. \& Yıldırım, S. (2015). A Case Study of Sharing Farm Machinery in Turkey. Internatıonal Journal of Natural and Engineering Sciences, 9 (3), 1-5.

[3] Bélanger, V., Vanasse, A., Parent, D., Allard, G. \& Pellerin, D. (2012). Development of agrienvironmental indicators to assess dairy farm sustainability in Quebec, Eastern Canada. Ecological Indicators, 23, 421-430. DOI: 10.1016/j.ecolind.2012.04.027.

[4] Bezuidenhout, C., Bodhanya, S. \& Brenchley, L. (2012). An analysis of collaboration in a sugarcane production and processing supply chain. British Food Journal, 114(6), 880-895. DOI: $10.1108 / 00070701211234390$.

[5] Blome, C., Paulraj, A. \& Schuetz, K. (2014). Supply chain collaboration and sustainability: A profile deviation analysis. International Journal of Operations \& Production Management, 34(5), 639-663. DOI: 10.1108/IJOPM-11-2012-0515. 
[6] Bourlakis, M., Maglaras, G., Aktas, E., Gallear, D. \& Fotopoulos, C. (2014). Firm size and sustainable performance in food supply chains: Insights from Greek SMEs. International Journal of Production Economics, 152, 112-130. DOI: 10.1016/j.jpe.2013.12.029.

[7] Butlin, J. (1987). Our Common Future. By World Commission on Environment and Development. London: Oxford University Press.

[8] Čiegis, R. (2009). Darnaus žemès ūkio plètra Lietuvoje. Vadybos mokslas ir studijos - kaimo verslų ir jų infrastruktūros plètrai, 16(1), 30-37.

[9] Dania, W. A., Xing, K. \& Amer, Y. (2018). Collaboration behavioural factors for sustainable agri-food supply chains: A systematic review. Journal of Cleaner Production, 186, 851-864. DOI: 10.1016/j.jclepro.2018.03.148.

[10] Dania, W. A., Xing, K. \& Amer, Y. (2016). Collaboration and sustainable agri-food suply chain: a literature review. MATEC Web of conferences, 58, 02004. DOI: $10.1051 /$ matecconf/20165802004.

[11] Ding, H., Huang, H. \& Tang, O. (2018). Sustainable supply chain collaboration with outsourcing pollutant-reduction service in power industry. Journal of Cleaner Production, 186, 215-228. DOI: 10.1016/j.jclepro.2018.03.039.

[12] Golebiewska, B., Grontkowska, A., Brelik, A. \& Gebska, M. (2020). Implementation of the principles of sustainable development by agricultural producers in Poland. European Research Studies Journal, 23(2), 121-133. DOI: 10.35808/ersj/1583.

[13] Hubeau, M., Marchand, F. \& Van Huylenbroeck, G. (2017). Sustainability experiments in the agri-food system: uncovering the factors of new governance and collaboration success. Sustainability, 9, 1027. DOI: 10.3390/su9061027.

[14] Hudnurkar, M., Jakhar, S. \& Rathod, U. (2014). Factors affecting collaboration in supply chain: a literature review. Procedia - Social and Behavioral Sciences, 133, 189-202. DOI: 10.1016/j.sbspro.2014.04.184.

[15] Jarrett, J., Morris, C., Wheeler, R. \& Winter, M. (2015). Literature review on farming collaboration [research report]. London: DEFRA.

[16] Kata, R. \& Kusz, D. (2015). Barriers to the implementation of instruments assisting sustainable development of agriculture. Scientific Papers Series management, Economic Engineering in Agriculture and Rural Development, 15(1), 242-251.

[17] Lorencowicz, E., Uziak, J. (2013). Farmers Collaboration - a Factor in the Development ff Sustainable Agriculture. In Lorencowicz, E., Uziak, J. \& Huygheboert, B., eds., Farm Machinery and Processes Management in Sustainable Agriculture (pp. 139-142). Lublin: University of Life Sciences.

[18] Lubell, M., Hillis, V. \& Hoffman, M. (2011). Innovation, cooperation, and the perceived benefits and costs of sustainable agriculture practices. Ecology and Society, 16(4), 23. DOI: 10.5751/ES-04389-160423.

[19] Miller, C. L. \& McCole, D. (2014). Understanding collaboration among farmers and farmers' market managers in southeast Michigan (USA). Journal of Agriculture, Food Systems, and Community Development, 4(4), 71-95. DOI: 10.5304/jafscd.2014.044.003.

[20] Panahifar, F., Byrne, P. J., Salam, M. A. \& Heavey, C. (2018). Supply chain collaboration and firm performance: The critical role of information sharing and trust. Journal of Enterprise Information Management, 31(2), 358-379. DOI: 10.1108/JEIM-08-2017-0114.

[21] Prager, K. (2015). Agri-environmental collaboratives for landscape management in Europe. Current Opinion in Environmental Sustainability, 12, 59-66. DOI: 10.1016/j.cosust.2014.10.009.

[22] Pretty, J. (2008). Agricultural sustainability: concepts, principles and evidence. Philosophical Transactions of the Royal Society B, 363(1491), 447-465. DOI: 10.1098/rstb.2007.2163. 
[23] Ramanathan, U., Bentley, Y. \& Pang, G. (2014). The role of collaboration in the UK green supply chains: An exploratory study of the perspectives of suppliers, logistics and retailers. Journal of Cleaner Production, 70, 231-241. DOI: 10.1016/j.jclepro.2014.02.026.

[24] Rota, C., Reynolds, N. \& Zanasi, C (2013). Sustainable food supply chains: The role of collaboration and sustainable relationships. International Journal of Business and Social Science, 4(4), 45-53.

[25] Rodríguez, D. (2019). Greenhouse Gas Emissions of Agriculture: A Comparative Analysis. In Saldarriaga-Noreña, H., Murillo-Tovar, M. A., Farooq, R., Dongre, R. \& Riaz, S., eds., Environmental Chemistry and Recent Pollution Control Approaches. London: IntechOpen. DOI: 10.5772/intechopen.84208.

[26] Schiefer, S., Gonzalez, C. \& Flanigan, S. (2015). More than just a factor in transition processes? The role of collaboration in agriculture. In Sutherland, L. A., Darnhofer, I., Wilson, G. A. \& Zagata, L., eds. Transition Pathways towards Sustainability in Agriculture: Case Studies from Europe (pp. 83-96). Wallingford: CABI. DOI: 10.1079/9781780642192.0000.

[27] Shelef, O., Fernández-Bayo, J. D., Sher, Y., Ancona, V., Slinn, H. \& Achmon, Y. (2018). Elucidating Local Food Production to Identify the Principles and Challenges of Sustainable Agriculture. In Galanakis, C. M., ed., Sustainable Food Systems from Agriculture to Industry (pp. 47-81). Cambridge (MA): Academic Press. DOI: 10.1016/B978-0-12-811935-8.000020.

[28] Sutherland, L. A., Darnhofer, I., Wilson, G. \& Zagata, L. (2015). Transition Pathways Towards Sustainability in Agriculture: Case Studies From Europe. Wallingford: CABI. DOI: 10.1079/9781780642192.0000.

[29] Sulewski, P., Kłoczko-Gajewska, A. \& Sroka, W. (2018). Relations between AgriEnvironmental, Economic and Social Dimensions of Farms' Sustainability. Sustainability, 10, 4629. DOI: $10.3390 /$ su10124629.

[30] Šūmane, S., Kunda, I., Knickel, K., Strauss, A., Tisenkopfs, T., des los Rios, I., Rivera, M., Chebach, T. \& Ashkenazy, A. (2018). Local and farmers' knowledge matters! How integrating informal and formal knowledge enhances sustainable and resilient agriculture. Journal of Rural Studies, 59, 232-241. DOI: 10.1016/j.jrurstud.2017.01.020.

[31] Thomson, A. M., Ramsey, S., Barnes, E., Basso, B., Eve, M,, Gennet, S., Grassini, P., Kliethermes, B., Matlock, M., McClellen, E., Spevak, E., Snyder, C. S., Tomer, M. D., van Kessel, C., West, T. \& Agric, G. W. (2017). Science in the Supply Chain: Collaboration Opportunities for Advancing Sustainable Agriculture in the United States. Agricultural \& Environmental Letters, 2, 170015, 1-6. DOI: 10.2134/ael2017.05.0015.

[32] Vachon, S. \& Klassen, R. D.(2008). Environmental management and manufacturing performance: The role of collaboration in the supply chain. International Journal of Production Economics, 111(2), 299-315. DOI: 10.1016/j.ijpe.2006.11.030.

[33] Velten, S., Jager, W. N. \& Newig, J. (2021). Success of collaboration for sustainable agriculture: a case study meta-analysis. Environment, Development and Sustainability. DOI: 10.1007/s10668-021-01261-y.

[34] Velten, S., Leventon, J., Jager, N. \& Newig, J. (2015). What Is Sustainable Agriculture? A Systematic Review. Sustainability, 7, 7833-7865. DOI: 10.3390/su7067833.

[35] Vilkè, R. \& Gedminaitè-Raudonè, Ž. (2020). Collaboration between government and agribusiness for biogas production: balanced development of rural sustainability. Viešoji politika ir administravimas 19(2), 298-313. DOI: 10.13165/VPA-20-19-2-11.

[36] Prager, K. (2015). Agri-environmental collaboratives for landscape management in Europe. Current Opinion in Environmental Sustainability 12, 59-66. DOI: 10.1016/j.cosust.2014.10.009.

[37] Wilson, P. (2017). Analysis of Farm Business Survey 2011-12 Business Management Practices [research report]. London: DEFRA. 
[38] Wilson, P., Lewis, M. \& Ackroyd, J. (2014). Farm Business Innovation, Cooperation and Performance. Nottingham: Rural Business Research.

[39] Vitunskienè, V. \& Vinciūnienè, V. (2014). Viešosios paramos reikšmè siekiant aplinkos darnumo Lietuvos žemès ūkyje. In Štreimikienè, D., ed., Darnus vystymasis: teorija ir praktika (pp. 252-281). Vilnius: Vilniaus universitetas.

Other sources

[40] Earles, R. (2005). Sustainable agriculture: An Introduction. A Publication of ATTRA, the National Sustainable Agriculture Information Service.

[41] USDA (1990). Food, Agriculture, Conservation, and Trade Act of 1990. Public Law 101-624, Title XVI, Subtitle A, Section 1603, Government Printing Office, Washington, DC. p. 123. 